\title{
Comparison of human and porcine insulin therapies in children with newly diagnosed diabetes mellitus
}

\author{
K. Zuppinger ${ }^{1}$, Ch. Aebi ${ }^{2}$, S. Fankhauser ${ }^{3}$, G. Herz ${ }^{4}$, R.P.Zurbrügg ${ }^{5}$, K. Schopfer ${ }^{6}$ and T.M. Neri ${ }^{7}$ \\ ${ }^{1}$ Department of Paediatrics, University of Bern, ${ }^{2}$ Department of Paediatrics, Aarau, ${ }^{3}$ Department of Medicine, Olten, ${ }^{4}$ Paediatric Office, \\ Basel, ${ }^{5}$ Department of Paediatrics, Biel and ${ }^{6}$ Institute for Clinical Microbiology and Immunology, St. Gallen, Switzerland; ${ }^{7}$ Istituto di \\ Clinica Medica e Nefrologia, Università di Parma, Parma, Italy
}

\begin{abstract}
Summary. A multicenter, longitudinal study of children below the age of 16 years with newly diagnosed Type 1 (insulin-dependent) diabetes treated either with porcine monocomponent insulin $(n=26)$ or semisynthetic human monocomponent insulin $(n=26)$ was performed during the first 24 months after onset of diabetes. The two groups were carefully matched for age, duration of disease symptoms, initial metabolic values, islet cell antibodies and HLA-DR antigens. During the 24-month observation period there was no significant difference between the two groups in respect to the clinical course, insulin dosage, $\mathrm{HbA}_{1}$ and residual B-cell activity.
\end{abstract}

The availability of human insulin for the treatment of children with Type 1 (insulin-dependent) diabetes mellitus has raised some hope of benefits both in respect to metabolic control and insulin antibody formation. The safety and efficacy of semisynthetic human insulin has been documented in diabetic adults [1]. Other studies published up to now have not shown conclusively whether the use of human insulin in diabetic children with Type 1 diabetes has any advantage compared to highly purified porcine insulin [2-6]. The purpose of the present work was to perform a longitudinal clinical and metabolic study in two similar groups of newly diagnosed diabetic children treated with either semisynthetic human or porcine insulin of equal purity.

\section{Subjects and methods}

\section{Patients}

The project was planned as a prospective multicenter study at four different paediatric services taking care of diabetic children (Department of Paediatrics, University of Bern, Kinderklinik Kantonspital Aarau, Kinderklinik Wildermeth Biel and a private paediatric office in Basel). Fifty-two children below the age of 16 years with a typical history of newly diagnosed and untreated Type 1 diabetes were included in the study. Half of the patients were treated by semisynthetic human insulin (Actrapid HM and Monotard HM, Novo, Copenhagen, Denmark) and the other half by porcine insulin (Actrapid MC and Monotard MC, Novo) of equal purity.

All patients received a mixture of Actrapid and Monotard in two daily injections $20-30 \mathrm{~min}$ before breakfast and supper. An age adapted diet containing approximately $45 \%$ of the calories as carbohydrates, $35 \%$ as fats and $20 \%$ as proteins was instructed [7] and adapted to the patients' needs. Insulin dosage was adjusted by patients or parents according to 3-4 daily urinary glucose and acetone
No child in either group had a real remission without necessitating insulin therapy. The prevalence of insulin antibodies increased slowly and was $62 \%$ in the group treated by human insulin and $52 \%$ in the porcine insulin-treated group after 24 months. The titres were generally low and there was no statistical difference between the two groups in respect to insulin antibody formation.

Key words: Type 1 (insulin-dependent) diabetes, children, human insulin, porcine insulin, insulin antibodies, HLA antigens.

tests [7]. The two patient groups (Table 1) were matched to be sufficiently similar in respect to sex, age, duration of diabetic symptoms, initial values of plasma glucose, urinary acetone, stable $\mathrm{HbA}_{1}$, presence of islet cell antibodies and distribution of HLA-DR antigens to allow a valid comparison. All children were followed at 3-month intervals when blood was drawn for stable $\mathrm{HbA}_{1}$. Insulin antibodies, were determined at 6-month intervals.

The insulin dosage was registered according to the patients' test booklets and the mean dose was calculated as units. $\mathrm{kg}$ body weight ${ }^{-1} \cdot$ day $^{-1}$.

The protocol of the study was approved by the ethical committee of the Department of Paediatrics, University of Bern.

Table 1

\begin{tabular}{lcc}
\hline Patients & Human insulin & Porcine insulin \\
\hline Number (sex) & $26(16 \mathrm{~F}, 10 \mathrm{M})$ & $26(14 \mathrm{~F}, 12 \mathrm{M})$ \\
Age (years) & $9.3 \pm 4.3$ & $9.7 \pm 4.2$ \\
(<5 years old) & $(4$ patients $)$ & $(5$ patients $)$ \\
History of symptoms & $3.2 \pm 2.7$ & $4.2 \pm 3.1$ \\
$\quad$ (weeks) & & \\
Plasma glucose (mmol/1) & $27.8 \pm 10.3$ & $24.5 \pm 7.4$ \\
Stable HbA $(\%)^{\mathrm{a}}$ & $14.4 \pm 2.5$ & $12.7 \pm 2.5$ \\
Islet cell antibodies & $21 / 26$ patients & $20 / 26$ patients \\
HLA antigens DR 4 & 20 & 18 \\
DR 3 & 11 & 14 \\
DR 1 & 8 & 5 \\
DR 7 & 3 & 1 \\
DR 2 & 2 & 0 \\
non DR 3 & 2 & 0 \\
or 4 & & \\
DR 3.4 & 7 & 7 \\
DR 1.4 & 4 & 3 \\
\hline
\end{tabular}

Initial values prior to insulin therapy. All variables are not statistically different 


\section{Methods}

Plasma glucose was measured by an automated hexokinase method. Stable $\mathrm{HbA}_{1}$ was estimated by a commercialised, strict-temperature regulated microcolumn method (Boehringer Mannheim, FRG) after removal of the labile component. Interassay coefficient of variation was $4.4 \%$ at $\mathrm{HbA}_{1} 7 \%, 3.4 \%$ at $10 \%$ and $2.6 \%$ at $16 \%$. Reference values in 20 normal children were $5.8-8.0 \%$.

Plasma C-peptide was determined by a commercialised RIA (Novo, Copenhagen, Denmark) with an interassay coefficient of variation of $15 \%$ at $125 \mathrm{pmol} / 1,7.5 \%$ at $250 \mathrm{pmol} / 1$ and $10.4 \%$ at $500 \mathrm{pmol} / \mathrm{l}$. Fasting reference values in 12 lean young adults were 178-630 pmol/l.

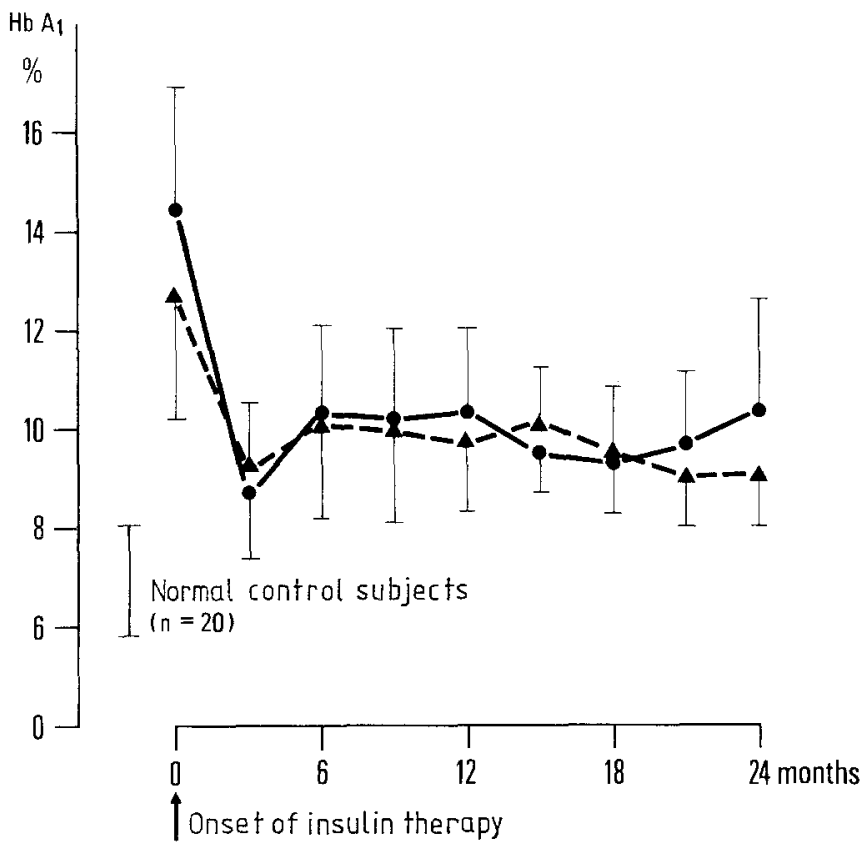

Fig. 1. Glycosylated haemoglobin during the first 24 months in children treated with human insulin $(n=26)$ and porcine insulin $(n=26) . \longrightarrow$ Human MC insulin; $\boldsymbol{\Lambda}-\boldsymbol{\Delta}$ porcine MC insulin

Table 2. Insulin dose and plasma C-peptide

\begin{tabular}{|c|c|c|c|c|}
\hline $\begin{array}{l}\text { Patients } \\
\text { ( } 26 \text { in each group) }\end{array}$ & Insulin & 1st year & 2nd year & \\
\hline $\begin{array}{l}\text { Mean insulin dose } \\
\left(\mathrm{U} \cdot \mathrm{kg}^{-1} \cdot \text { day }^{-1}\right)\end{array}$ & $\begin{array}{l}\text { Human } \\
\text { Porcine }\end{array}$ & $\begin{array}{l}0.53 \pm 0.23 \\
0.52 \pm 0.26\end{array}$ & $\begin{array}{l}0.67 \pm 0.23 \\
0.63 \pm 0.22\end{array}$ & NS \\
\hline $\begin{array}{l}\text { Maximal plasma } \\
\text { C-peptide }(\mathrm{pmol} / \mathrm{1})\end{array}$ & $\begin{array}{l}\text { Human } \\
\text { Porcine }\end{array}$ & $\begin{array}{l}0-898(106)^{\mathrm{a}} \\
0-686(150)^{\mathrm{a}}\end{array}$ & $\begin{array}{l}0-436(93)^{\mathrm{a}} \\
0-498(80)^{\mathrm{a}}\end{array}$ & NS \\
\hline
\end{tabular}

a Range (median)
Insulin antibodies were primarily determined by using $125-\mathrm{J}$ ox insulin (Novo) with amberlite separation according to a modified method by Melani et al. [8]. The interassay coefficient of variation was $7.9 \%$. Results are given as \% binding of $125-\mathrm{J}$ insulin. Values below $1.7 \%$ were considered to be negative. For comparison the classical immunoelectrophoresis technique was used [9] with values below $0.1 \%$ considered to be negative. In addition, parallel determinations were done using 125-J pork and human insulin (Novo) with amberlite separation.

Islet cell antibodies were assessed by an indirect immunofluorescene technique on ultrathin $(<4 \mu \mathrm{m})$ sections of freshly frozen human pancreas [10]. Reproducibility of assays was determined by including both a positive control serum at a titre of 1:64 with an interassay variation of not more than one dilution step and a negative control serum.

HLA typing was performed using the standardised microlymphocytotoxicity technique [11].

\section{Statistical analysis}

All values are given as mean \pm 1 standard deviation (SD) if not otherwise stated. For statistical analysis the $\mathrm{X}^{2}$-test, Fisher's exact test, Wilcoxon test and Spearman rank test were applied.

\section{Results}

The clinical course of the two groups of children treated by semisynthetic human or porcine insulin was similar. No patient in either group entered a full remission with normalisation of plasma glucose levels and glycosylated haemoglobin values while receiving no insulin. This similar clinical course was also reflected by an almost identical mean insulin dosage (Table 2) together with a similar mean $\mathrm{HbA}_{1}$ (Fig. 1) during the whole observation period.

Severe hypoglycaemic episodes with loss of consciousness necessitating either the administration of glucagon or i.v. glucose during the first 2 years of therapy occurred in three patients on porcine, and six patients on human insulin. This difference was not significant.

Residual B-cell activity as estimated by casual plasma C-peptide measurements (Table 2) also showed no difference between the two groups.

The prevalence of insulin antibodies increased slowly during the 24-month observation period when it was higher in patients treated by human than in those treated by porcine insulin (Table 3 ). The titres were generally very low in both groups showing a gradual

Table 3. Prevalence of insulin antibody response ( $n=26$ patients in each group)

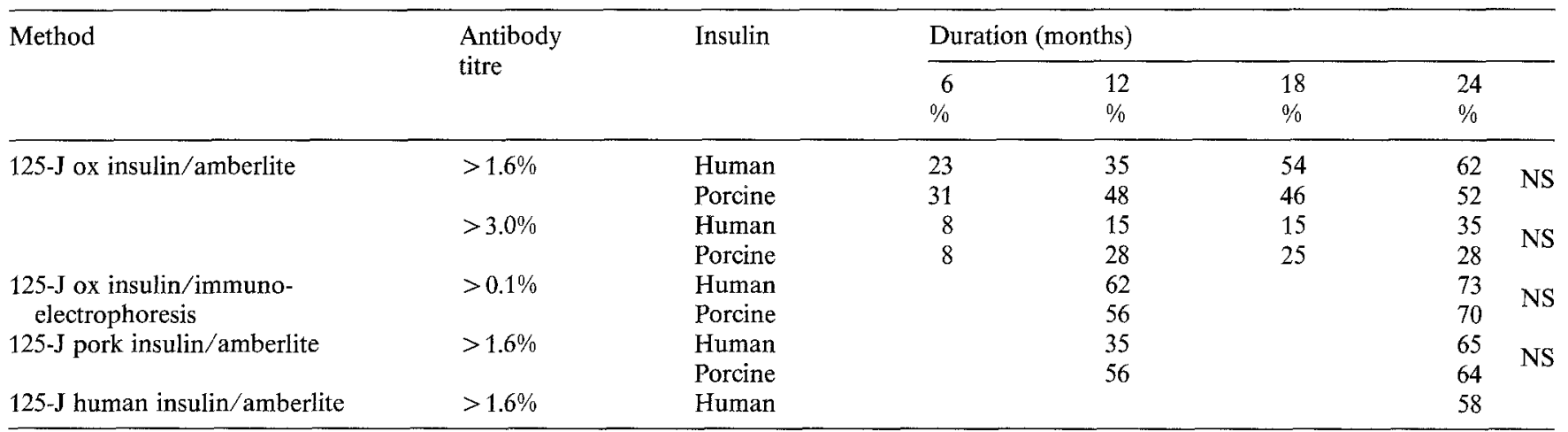


increase over the first 24 months (Fig. 2). The prevalence of responders (titre $>1.6 \%$ ) and moderate responders (titre $>3.0 \%$ ) was not significantly different in the two groups (Table 3 ). There was only one high responder in each group (titre $>20 \%$ ). Applying different species of labelled insulin including $125-\mathrm{J}$ human insulin and different methods of separation also did not show any statistically significant difference between both groups (Table 3). Furthermore, insulin antibody titres did not correlate with either metabolic control $\left(\mathrm{HbA}_{1}\right)$ or insulin dosage.

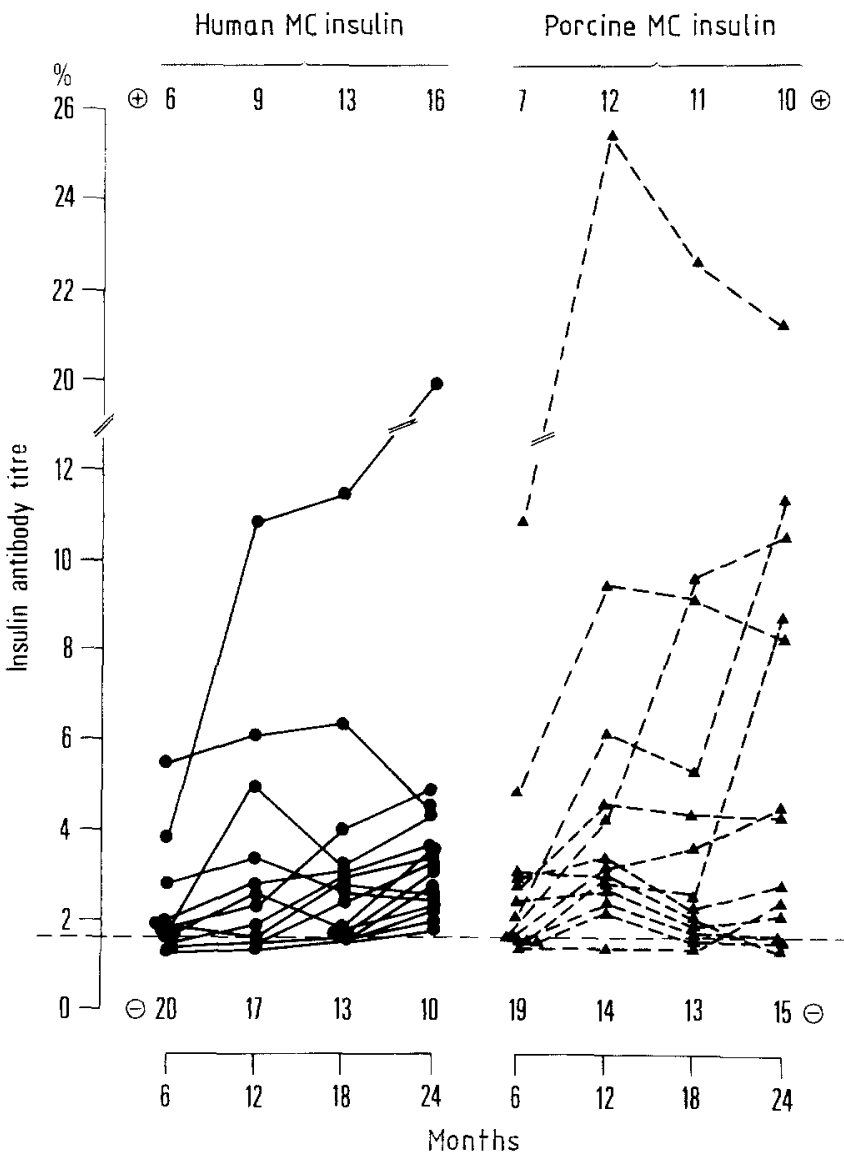

Fig. 2. Development of insulin antibodies in children with newly diagnosed diabetes treated with human insulin $(n=26)$ or porcine insulin $(n=26)$. Values consistently below $1.7 \%$ are not given

\section{Discussion}

Care was taken in this multicenter prospective study to achieve an optimal match of the two groups of children with newly diagnosed diabetes treated with either semisynthetic human or porcine insulin. The similar age range is of importance as younger children have a more rapid decline of B-cell residual activity than older children [12]. The distribution of the HLA-DR genotypes showing no significant difference is of importance in view of the dissimilar clinical course in different HLA genotypes [12-14].

The insulin requirement of human insulin in contrast to another study [15] was not superior to the one of porcine insulin and the metabolic control was not worse in the human insulin group [3]; but rather was it equal in both groups in confirmation of others [15]. Residual B-cell activity decreased rapidly and equally in both groups over the 24-month observation period which is in accordance with the usual clinical course [14].

The immunological response to exogenous insulin is generally more marked in children than in adults [16]. The overall prevalence of insulin antibody responders in our study was rather high and gradually increased up to 24 months after onset of therapy. For comparison insulin antibody determinations were performed by immunoelectrophoresis showing a prevalence in all 52 children of $58 \%$ at 12 months which is similar to that found by others $[6,17]$. In contrast to other studies $[4,6]$, both prevalence and degree of insulin antibody response was not significantly smaller in our patients treated with human insulin. The reason for this discrepancy is not clear. Methodological differences were excluded by performing parallel determinations (Table 3) applying the same methods as in other studies $[4,6]$. As the responder rate in our study continued to increase slowly with duration of therapy and the follow-up was shorter in the other studies $[4,6]$ a longer observation and a larger number of patients may be necessary for clarification.

As in adult diabetic patients $[18,19]$ our children bearing the HLA-DR 3 antigen had a significantly

Table 4. Relation of insulin antibody formation to HLA DR-antigens

\begin{tabular}{|c|c|c|c|c|c|c|}
\hline & Responders & Non-responders & & $\begin{array}{l}\text { Moderate and } \\
\text { high responders }\end{array}$ & $\begin{array}{l}\text { Non- and } \\
\text { low responders }\end{array}$ & \\
\hline $\begin{array}{l}\text { Insulin } \\
\text { antibodies }\end{array}$ & $>1.6 \%$ & $\leqq 1.6 \%$ & & $>3 \%$ & $\leqq 3 \%$ & \\
\hline Patients (n) & 29 & 23 & & 18 & 34 & \\
\hline $\begin{array}{l}\text { HLA antigens } \\
\text { DR } 4 \\
\text { DR } 3 \\
\text { DR } 1\end{array}$ & $\begin{array}{r}23 \\
9 \\
10\end{array}$ & $\begin{array}{r}15 \\
16 \\
3\end{array}$ & $\begin{array}{l}\mathrm{X}^{2} \text {-Test } \\
\mathrm{NS} \\
p<0.01 \\
\mathrm{NS}\end{array}$ & $\begin{array}{r}13 \\
4 \\
9\end{array}$ & $\begin{array}{r}25 \\
21 \\
4\end{array}$ & $\begin{array}{l}\mathrm{X}^{2} \text {-Test } \\
\text { NS } \\
p<0.01 \\
p<0.005\end{array}$ \\
\hline $\begin{array}{l}\text { HLA phenotyp } \\
\text { DR } 3.4 \\
\text { DR } 1.4\end{array}$ & $\begin{array}{l}5 \\
7\end{array}$ & $\begin{array}{l}9 \\
0\end{array}$ & $\begin{array}{l}\mathrm{NS} \\
p<0.001^{\mathrm{a}}\end{array}$ & $\begin{array}{l}1 \\
6\end{array}$ & $\begin{array}{r}13 \\
1\end{array}$ & $\begin{array}{l}p<0.025 \\
p<0.005\end{array}$ \\
\hline
\end{tabular}

a Fisher's exact test 
lower prevalence of insulin antibody formation than with other DR antigens (Table 4). Prevalence of HLADR 3 in our children treated with porcine insulin was somewhat higher than in the group treated with human insulin (Table 1) which may have had some influence on insulin antibody formation. The DR 4 antigen in confirmation with some earlier studies $[18,19]$ had no influence on antibody formation to insulin, therefore not confirming the tendency to develop insulin antibodies more rapidly in DR 4 antigen positive children observed by others $[4,17,20]$.

In our group, insulin antibody formation, especially at higher titres, both in response to human and porcine insulin correlated significantly with HLA-DR 1 and DR 1.4 (Table 4). This significantly increased prevalence of DR 1.4 phenotype has already been described as a new DR specificity recognised either by monoclonal antibodies [21] or by alloantisera [22]. This specificity was found significantly associated with rheumatoid arthritis [21]. The increased frequency of both DR 1 and DR 1.4 specificities in our patients with Type 1 diabetes was not found in other populations and could possibly be ascribed to ethnical differences.

In spite of the multicenter nature of our study, with the possible disadvantage of different clinical guidance of patients and their families, our controlled study revealed no discernable difference in clinical course, metabolic control and development of insulin antibodies in children treated with semisynthetic human insulin in comparison to porcine insulin of equal purity.

Acknowledgments. We are grateful to Ms. R. Kirchhofer and Ms. E. Pfenninger for excellent technical skills. We thank the Novo company and Dr. Stein for support and for provision of C-peptide RIA kits. This work was supported in part by the Swiss National Science Foundation grant No.3.963.080 and 3.976.082.

\section{References}

1. Owens DR, Jones MK, Hayes TM, Heding LG, Alberti KGMM, Home PD, Burrin JM, Newcombe RG (1981) Human insulin: study of safety and efficacy in man. Br Med J 282: 1264-1266

2. Greene SA, Smith MA, Cartwright B, Baum JD (1983) Comparison of human versus porcine insulin in treatment of diabetes in children. Br Med J 287: 1578-1579

3. Mann NP, Johnston DI, Reeves WG, Murphy MA (1983) Human insulin and porcine insulin in the treatment of diabetic children: comparison of metabolic control and insulin antibody production. Br Med J 287: 1580-1582

4. Schernthaner G, Borkenstein M, Fink M, Mayr WR, Menzel J, Schober E (1983) Immunogenicity of human insulin (Novo) or pork monocomponent insulin in HLA-DR-typed insulin-dependent diabetic individuals. Diabetes Care 6 [Suppl 1]: 43-48

5. Sonnenberg GE, Berger M (1983) Human insulin: Much ado about one amino acid? Diabetologia 25: 457-459

6. Heding LG, Marshall MO, Persson B, Dahlquist G, Thalme B, Lindgren $F$, Akerblom $\mathrm{HK}$, Rilva A, Knip M, Ludvigsson J, Stenhammar L, Strömberg L, Sovik O, Baevre H, Wefring K, Vidnes J, Kjaergard JJ, Bro P, Kaad PH (1984) Immunogenicity of monocomponent human and porcine insulin in newly diagnosed Type 1 (insulin-dependent) diabetic children. Diabetologia 27: 96-98

7. Berner Datenbuch der Pädiatrie (1985) 2nd edn. Gustav Fischer, Stuttgart New York, pp 93-143

8. Melani F, Ditschuneit H, Bartelt KM, Friedrich H, Pfeiffer EF (1965) Über die radioimmunologische Bestimmung von Insulin im Blut. Klin Wochenschr 43: 1000-1007

9. Christiansen AH (1973) Radioimmunoelectrophoresis in the determination of insulin binding to IgG-methodological studies. Horm Metab Res 5: 147-154

10. Bottazzo GF, Christensen AF, Doniach D (1974) Islet-cell antibodies in diabetes mellitus with autoimmune polyendocrine deficiencies. Lancet II: $1279-1282$

11. Garotta G, Neri TM (1981) HLA-DR typing by complement-dependent B lymphocyte lysis. In: Lefkovits I, Pernis B (eds) Immunological methods II. Academic, New York, pp 163-185

12. Hoogwerf BJ, Rich SS, Barbosa JJ (1985) Meal-stimulated Cpeptide and insulin antibodies in type 1 diabetic subjects and their nondiabetic siblings characterized by HLA-DR antigens. Diabetes 34: 440-445

13. Ludvigsson J, Samuelsson U, Beauforts C, Deschamps I, Dorchy H, Drash A, Francois R, Herz G, New M, Schober E (1986) HLA-DR 3 is associated with a more slowly progressive form of Type 1 (insulin-dependent) diabetes. Diabetologia 29: $207-210$

14. Knip M, Ilonen J, Mustonen A, Akerblom HK (1986) Evidence of an accelerated B-cell destruction in HLA-Dw3/Dw4 heterozy. gous children with Type 1 (insulin-dependent) diabetes. Diabetologia $29: 347-351$

15. Hürter P, von Schütz W, Zick R, Stolzenbach K (1985) Klinische Erfahrungen mit der Substitution biosynthetischen Humaninsulins bei Kindern und Jugendlichen mit Typ-1-Diabetes. Monatschr Kinderheilk 133: 277-283

16. Akerblom HK, Mäkelä AL (1977) Insulin antibodies in the serum of diabetic children treated from the diagnosis of the disease with highly purified insulins. Acta Paediatr [Suppl 270]: 69-79

17. Ludvigsson $\mathbf{J}$ (1984) Insulin antibodies in diabetic children treated with monocomponent porcine insulin from the onset: relationship to B-cell function and partial remission. Diabetologia 26: $138-141$

18. Schernthaner G, Ludwig H, Mayr WR (1979) Immunoglobulin $\mathrm{G}$-insulin antibodies and immune region-associated alloantigens in insulin-dependent diabetes mellitus. J Clin Endocrinol Metab 48: 403-407

19. Reeves WG, Barr D, Douglas CA, Gelsthorpe K, Hanning I, Skene A, Wells L, Wilson RM, Tattersall RB (1984) Factors governing the human immune response to injected insulin. Diabetologia 26: 266-271

20. Almer LO, Ekberg G, Fankhauser S, Home PD, Worth R, Sailer S, Kurtz AB, Christy M (1985) A prospective study of the immunogenicity of porcine insulin in HLA-typed new insulin-treated diabetics. Diabetes Res 2: 221-224

21. Colombani J, Lepage $V(1984)$ HLA monoclonal antibody registry: third listing. Tissue Antigens 24: 209-214

22. Lepage V, Alcalay D, Douay C, Mallet C, Loiseau P, Degos L, Colombani M, Colombani J (1985) Evidence for a new HLA class II determinant present on cells from HLA-DR1 and/or -DR4 individuals. Tissue Antigens 25: 96-102

Received: 26 May 1987

and in revised form: 27 October 1987

Professor K. Zuppinger

Medizinische Universitäts-Kinderklinik

Inselspital

CH-3010 Bern

Switzerland 